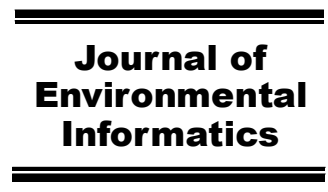

www.iseis.org/jei

\title{
Spatial and Temporal Analysis of Evapotranspiration Using Satellite Remote Sensing Data: A Case Study in the Gezira Scheme, Sudan
}

\author{
M. A. Bashir ${ }^{1, *}$, H. Tanakamaru ${ }^{1}$, and A. Tada ${ }^{2}$ \\ ${ }^{I}$ Department of Food Systems and Field Sciences, Graduate School of Science and Technology, Kobe University, Kobe 657-8501, Japan \\ ${ }^{2}$ Faculty of Agriculture, Kobe University, Kobe 657-8501, Japan
}

Received 19 January 2007; revised 20 January 2009; accepted 1 April 2009; published online 10 June 2009

\begin{abstract}
Current methods for estimating evapotranspiration (ET), the essential variable in irrigation performance and water management, largely neglect the spatial and temporal variations in ET. Accurate regional ET maps would provide valuable information on actual crop water use. The objective of this study was mainly to evaluate a Pilot Project (PP) supported by the Food and Agriculture Organization of the United Nations (FAO). In this study, Surface Energy Balance Algorithm for Land (SEBAL) model was used to assist the evaluation attempt. The performance of the ET model was evaluated by comparing the predicted daily ET with values derived by conventional methods based on ground measurements and meteorological data on 6 Sepetmber, 25 Sepetmber, 28 November and 11 December. The ET values from SEBAL showed good agreement with the actual values measured in the field. The amount of water required to satisfy the irrigation needs at canal level was monitored and successfully estimated. However, during November the daily estimated water demand ranged from $15667 \mathrm{~m}^{3}$ for Tereifi minor to $28954 \mathrm{~m}^{3}$ for Heleiwa west minor canal. The average values of relative irrigation supply (RIS) were determined as 0.73 which indicates improvements in operational performance of minor canals. The results of this study demonstrate that remote sensing measurements and limited ground data can be used to successfully estimate ET and assess irrigation performance in areas of poor infrastructure. Results achieved support previous opinion that repeatedly recommended the PP as a crucial step for water management in the Gezira scheme, Sudan.
\end{abstract}

Keywords: evapotranspiration, irrigation performance, Gezira scheme, remote sensing, SEBAL

\section{Introduction}

The Gezira scheme is Sudan's oldest and largest gravity irrigation system, located between the Blue Nile and the White Nile. Started in 1925 and progressively expanded thereafter, it covers about 880,000 ha, receives water from the Sennar Dam on the Blue Nile and is divided into some 114,000 tenancies. Farmers operate the scheme in partnership with the government and the Sudan Gezira Board (SGB) that provides administrative, credit and marketing services. The scheme has played an important role in the economic development of Sudan, serving as a major source of foreign exchange earnings and of government revenue. It has also contributed to national food security and to generating a livelihood for the 2.7 million people who live in the command area of the scheme.

Since its stabilshment, the task of irrigation management was entrusted to the SGB and Minstry of Irrigation. Recently, low crop productivity, poor water management performance, insufficient financial for operation and maintenance costs, and very low water fee collection efficiencies from the farmers

${ }^{*}$ Corresponding author. Tel.: +81 78 8035896; fax: +81 788035897.

E-mail address: bashir70us@yahoo.com (M. A. Bashir).

ISSN: 1726-2135 print/1684-8799 online

(C) 2009 ISEIS All rights reserved. doi:10.3808/jei.200900143 open the door to partially transfer the authority of irrigation management to local irrigation committee. Abdel Hakam block was selected for testing the irrigation management transfer process in a pilot project (PP) supported by the FAO during 2000 $\sim 2002$. About 12 local irrigation committees were formed at the block level.

Under the new structure of irrigation management, the local irrigation committee responsible for providing all services related to the operation and maintenance of the minor irrigation system. However, irrigation responsibilities of the upper system (main canals) are shared between SGB and Ministry of Irrigation.

The PP was evaluated for a variety of management objectives to assess the irrigation performance. Numerous indicators have been proposed during last decades such as the area irrigated, crop patterns and distribution and delivery of water (Abernethy, 1986; Levine, 1982; Molden and Gates, 1990).

This study was conducted to assess the variations of some performance critera during the implementation period of the PP such as spatial ET, crop yield and relative irrigation supply.

\section{Methodology}

\subsection{Study Area and Data Used}

This study was focused on Abdel Hakam block (Figure 1) 

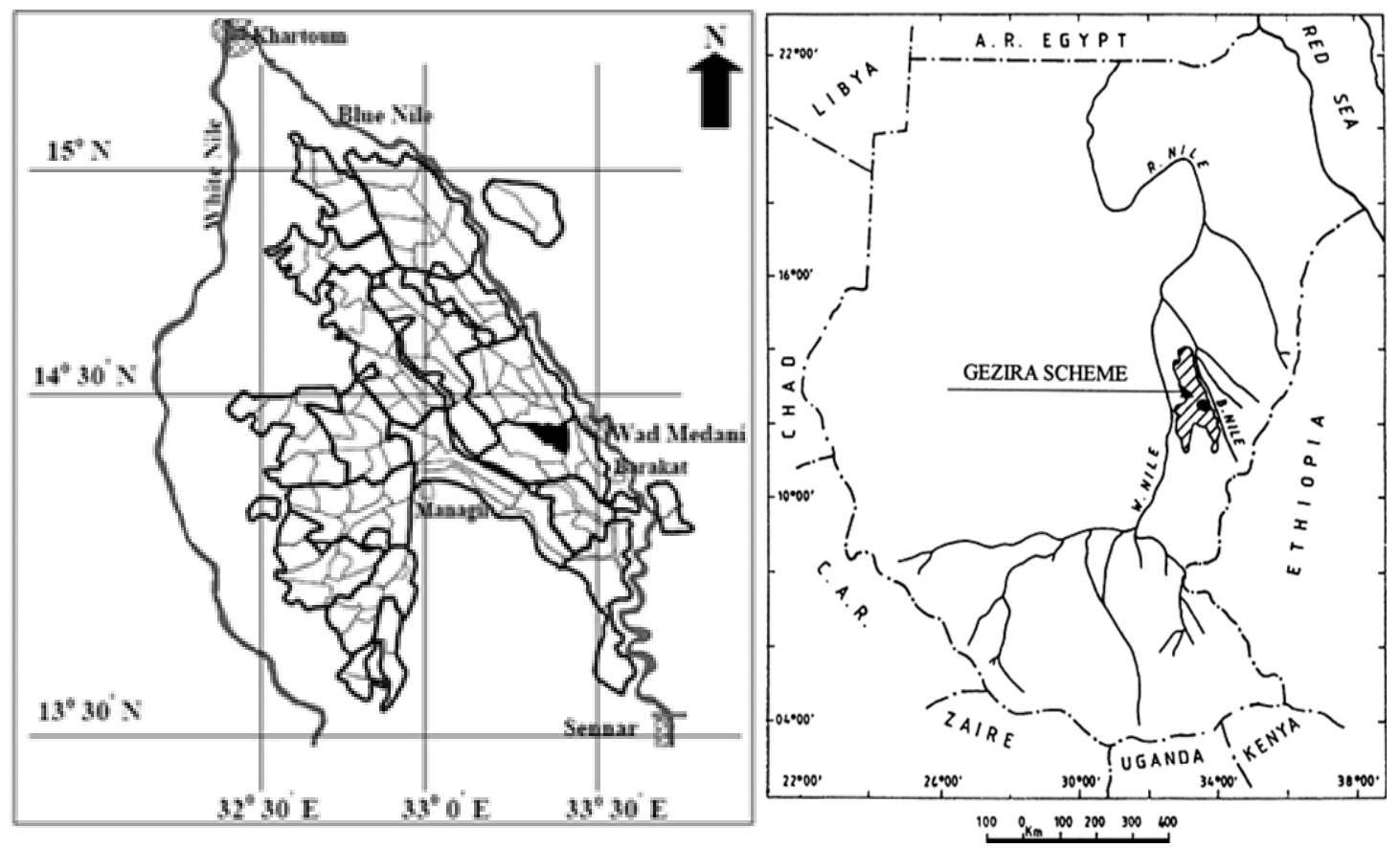

Figure 1. The location of the study area (Abdel Hakam block is shown as black).

which is located in the Central Group of the Gezira scheme (Latitude $14^{\circ} 23^{\prime} \mathrm{N}$ and Longitude $33^{\circ} 23^{\prime} \mathrm{E}$, elevation $409 \mathrm{~m}$ ) with total irrigation command area around 6,000 ha and crop intensity of $80 \%$. The main summer crops cultivated during the $2001 /$ 02 season were sorghum $(2,495 \mathrm{ha})$, cotton (768 ha) groundnuts (336 ha), vegetables (204 ha) and fodder (158 ha). Four Landsat Enhanced Thematic Mapper Plus (ETM+) images acquired during the 2001 and 2002 seasons were used to analyze the temporal and spatial distributions of ET in the study area. The images, selected coincidentally with the PP initiated in Abdel Hakam, were dated 6 September 2001, 11 December 2001, 25 September 2002 and 28 November 2002.

\subsection{The SEBAL Model}

Surface energy balance used for remote sensing-based ET estimations is proving to be the most recently accepted technique for aerial ET estimation (Morse et al., 2000). SEBAL is one of such models utilizing Landsat and images from other sensors with a thermal infrared band to solve the energy balance equation and, consequently, to generate an aerial map of ET (Bastiaanssen et al., 1998a, b; Morse et al., 2000).

SEBAL requires weather data such as solar radiation, wind speed, precipitation, air temperature and relative humidity in addition to satellite images with visible, near infrared and thermal bands. In the absence of horizontally advective energy, the surface energy balance of the land surface can be expressed as:

$\lambda E=R n-H-G$

where $\lambda E$ is latent heat flux, $R n$ is net radiation at the surface, $H$ is sensible heat flux, and $G$ is soil heat flux. All fluxes are expressed in $\mathrm{W} / \mathrm{m}^{2}$.

Net radiation is the algebraic sum of the shortwave and long-wave radiative fluxes and is computed as:

$R n=(1-\alpha) R_{s}+\left(\varepsilon L_{\text {in }}-L_{\text {out }}\right)$

where $\alpha$ is surface albedo; $R_{s}$ is solar radiation $\left(\mathrm{W} / \mathrm{m}^{2}\right) ; \varepsilon$ is land surface emissivity; and $L_{\text {in }}$ and $L_{\text {out }}$ are incoming and outgoing long-wave radiation $\left(\mathrm{W} / \mathrm{m}^{2}\right)$. The $\alpha$ was determined by integrating spectral reflectance in the six shortwave bands of the Landsat images, and $L_{\text {in }}$ and $L_{\text {out }}$ were computed as functions of surface temperature derived from the satellite images. The $\varepsilon$ was computed from Normalized Difference Vegetation Index (NDVI) derived from two of the shortwave bands (red and near-infrared) as explained by Van de Griend \& Owe (1993):

$\varepsilon=1.009+0.0047 \operatorname{Ln}(N D V I)$

The outgoing long-wave radiation $L_{\text {out }}$ is determined by Stefan-Boltzman's law $\left(\sigma=5.67 \times 10^{-8}\right)$ as a function of surface temperature $\left(T_{s}\right)$ and surface emissivity $\left(\varepsilon_{o}\right)$, while incoming long-wave radiation $L_{i n}$ was determined from the air temperature $\left(T_{a}\right)$ and atmospheric emissivity $\left(\varepsilon_{a}\right)$. The complete set of equations is explained in the FAO-56 publication (Allen et al., 1998):

$L_{\text {out }}=\varepsilon_{o} \sigma \times T_{s}^{4}$
$L_{\text {in }}=\varepsilon_{a} \sigma \times T_{a}^{4}$

Soil heat flux $(G)$ is expressed as a fraction of net radia- 
tion, the fraction being a function of surface radiometric temperature $\left(T_{s}\right)$ and albedo $(\alpha)$, as suggested by Bastiaanssen et al. (1998a):

$$
\frac{G}{R n}=\frac{T_{s}}{\alpha}\left(0.0032 \alpha+0.0062 \times \alpha^{2}\right)\left(1-0.98 N D V I^{4}\right)
$$

The latent heat flux $\lambda E$ is computed as the residue of surface energy budget as shown in Equation (1). The sensible heat flux $H\left(z_{o h}, z\right)$ between a surface and a level $z$ was evaluated using a bulk resistance approach. Sensible heat flux, aerodynamic resistance and friction velocity were estimated as described by Bastiaanssen et al. (1998a) and Tasumi (2003):

$H\left(z_{o h}, z\right)=\rho_{a} C_{p} \frac{T_{s}-T_{a}(z)}{r_{a h}\left(z_{o h}, z\right)}$

where $\rho_{a}$ is the air density; $C_{p}$ is air specific heat $(1,004) ; T_{a}$ is the air potential temperature; and $z_{o h}$ is the scalar roughness for heat. The aerodynamic resistance for the layer between $z_{o h}$ and $z$ is defined as:

$r_{a h}\left(z_{o h}, z\right)=\frac{1}{k u_{*}}\left[\ln \left(\frac{z-d}{z_{o h}}\right)-\psi_{h}\left(z, L_{M O}\right)\right]$

where $k$ is Von Karman's constant; $z_{\text {oh }}$ is the roughness length for momentum; $d$ is the displacement height; and $\psi_{h}$ is stability correction factor for heat transport. The friction velocity $u_{*}$ is given by:

$u_{*}=\frac{k u(z)}{\ln \left(\frac{z-d}{z_{\text {om }}}\right)-\psi_{m}\left(z, L_{M O}\right)}$

where $u(z)$ is the wind speed at level $z ; z_{o m}$ is the roughness length for momentum; and $\psi_{m}$ is the stability correction factor for momentum. Surface roughness for momentum transport was estimated according to the empirical concept of Moran and Jackson (1991) as shown in Equation (14), whereas the components of stability correction functions and Monin-Obukhov length were calculated as follows (Paulson, 1970):

$$
\begin{aligned}
& \psi_{h}=2 \times \ln \left(\frac{1+x^{2}}{2}\right) \\
& \psi_{m}=2 \times \ln \left(\frac{1+x}{2}\right)+\ln \left(\frac{1+x^{2}}{2}\right)-2 \times A \tan (x)+\frac{\pi}{2} \\
& x=\left[1-16 \times \frac{z}{L}\right]^{1 / 4}
\end{aligned}
$$

$$
L_{M O}=-\frac{\rho_{a} C_{p} u_{*}^{3}}{k g H}\left(\frac{T_{s}+T_{a}(z)}{2}\right)
$$

where parameters $g$ and $k$ are gravity acceleration and Von Karman's constant, respectively. The mean value of $T_{s}$ and $T_{a}$ represents the air temperature of the layer between $z_{\text {oh }}$ and $z$. The roughness length for heat $z_{\text {oh }}$ was set to $0.1 z_{\text {om }}$. The roughness for momentum was deduced from NDVI:

$z_{\text {om }}(x, y)=\exp (a \cdot \operatorname{NDVI}(x, y)+b)$

where $a$ and $b$ are constants calibrated for each image.

Once the instantaneous $\lambda E$ flux is computed from Equation (1), then the actual evapotranspiration $\left(E T_{a}\right)$ for the entire day ( 24 hours) of the image dates is calculated by first determining the evaporative fraction $(\Lambda)$ and the daily net radiation $\left(R n_{24 h o u r}\right)$. The 24-hour net radiation was computed according to De Bruin (1987), while the evaporative fraction was computed according to Equation (15). Experimental evidence indicates that $\Lambda$ is a constant during cloud-free days (Nichols and Cuenca, 1993) and that there is little difference between midday $\Lambda$ and the all-day average (Shuttleworth et al., 1989). Van Oevelen et al. (1993) and Kustas et al. (1994) showed that $\Lambda$ is an adequate tool for describing the surface energy partitioning for time scales of one day or less and daily integrated values of $(R n-G)$ using satellite data:

$\Lambda=\frac{\lambda E T}{(R n-G)}$

The calculation of $E T_{a}$ includes the transformation of $R n_{24 h o u r}$ from W.m ${ }^{-2}$ to $\mathrm{mm}$ per day by the surface temperature dependent latent heat of vaporization (Equation 16) as follows:

$E T_{a}=\frac{8.64 \times 10^{7}}{\lambda} \Lambda \times R n_{24 h o u r}$

where $E T_{a}$ is the actual evapotranspiration $(\mathrm{mm} / \mathrm{d}) ; R n_{24 h o u r}$ is the average daily net radiation $\left(\mathrm{W} / \mathrm{m}^{2}\right)$; and $\lambda$ is the energy required to evaporate the water.

\subsection{Measurement of the Actual ET}

The Landsat 7 images were processed for 2001 and 2002 seasons since these years coincided with the experimental results of $E T_{a}$ obtained by water balance (WB) approach. The daily amounts of water that move into and out of the root zone are shown in Equation (17):

$$
\Delta S=I+P-E T-D-R
$$

where $\Delta S$ is the total water in the root zone; $I$ is the irrigate- 

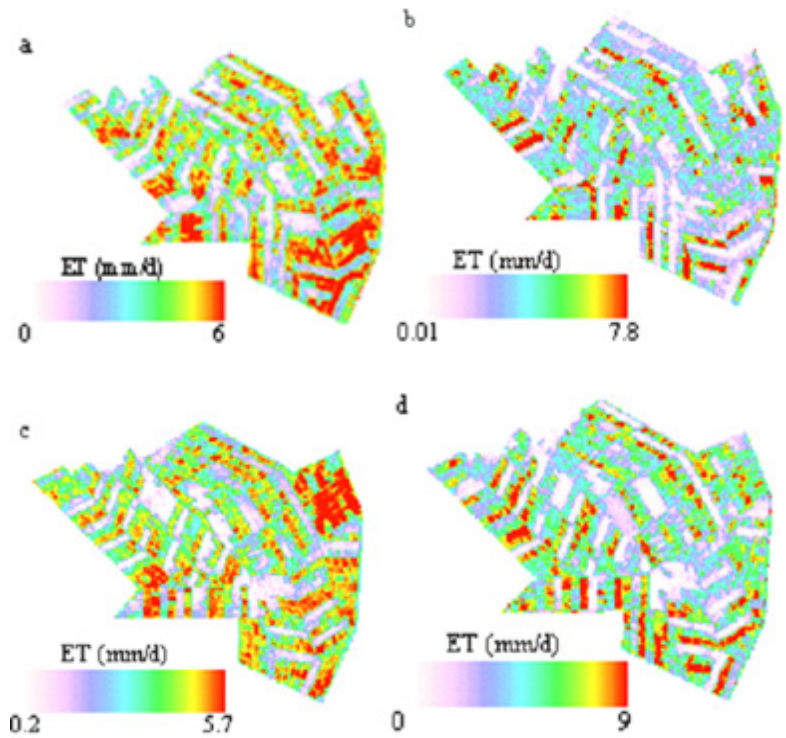

Figure 2. Spatial and temporal variation of actual ET by SEBAL over the study area during satellite overpass, Sep.6 (a), Dec.11 (b), Sep.25 (c) and Nov.28 (d).

ion water applied; $P$ is the rainfall; $D$ is the drainage or deep percolation below the root zone; and $R$ is the runoff. Under the condition of Gezira heavy clay soils runoff, deep percolation and capillary rise are negligible, therefore, the water balance equation can be simplified as $\Delta S=I+P-$ $E T_{a}$.

Consequently, daily $E T_{a}$ for each irrigation cycle was calculated from differences of volumetric soil moisture content according to Equation (18):

$E T_{a}=\left[\frac{p+\sum_{i=1}^{n}\left(\theta_{1 i}-\theta_{2 i}\right) \Delta z_{i}}{\Delta t}\right]$

where $E T_{a}$ is the actual evapotranspiration during the irrigation cycle $(\mathrm{mm} / \mathrm{d}) ; p$ is the effective rainfall $(\mathrm{mm})$ between the postand preirrigation gravimetric sampling; $n$ is the number of soil layers from which soil samples were taken; $\theta_{1 i}$ and $\theta_{2 i}$ are the volumetric soil moisture content during the post and preirrigation cycles, respectively, for the soil layer $i ; \Delta t$ is the time elapsed between $\theta_{l i}$ and $\theta_{2 i}$ (days); and $\Delta z_{i}$ is the thickness of each soil layer sampled $(\mathrm{mm})$. The gravimetric moisture content $(\mathrm{w} / \mathrm{w})$ was converted to volumetric values $(\mathrm{v} / \mathrm{v})$ by multiplying the gravimetric moisture content by the dry bulk density, according to Equation (19):

$\theta=\theta_{g} \times B D$

where $\theta_{g}$ is the gravimetric moisture content of the soil (\%) and $B D$ the soil layer's bulk density. The data of soil volume weight ratios introduced by Abdine and Farbrother (1969) were used to generate regression equations that relate soil bulk den- sity to soil depth and moisture content. The second degree polynomial equations were used in the regression for depths of 0 to $60 \mathrm{~cm}$, while linear regression was used for depths of 60 to $100 \mathrm{~cm}$. The generated regression equations were used to transform the gravimetric moisture content to volumetric values (Abdelhadi et al., 2006).

\section{Results and Discussions}

Figure 2 shows the spatial distribution of actual daily ET as estimated by SEBAL over the entire study area on four Julian Days (JDs): 6 September, 11 December, 25 September and 28 November. Table 1 summarizes the calculated statistics obtained from the frequency distribution diagrams displayed against the respective $E T_{a}$ maps, whereas Figure 3 represents the frequency distribution at each pixel. The $E T_{a}$ for the four JDs ranged from 0 to $6,0.01$ to $7.8,0.2$ to 5.7 and 0 to $9 \mathrm{~mm} / \mathrm{d}$, respectively (Figure 2). It is clear from Figure 3 that the September images have similar histograms with two peaks, the first one (less than $2 \mathrm{~mm} / \mathrm{d}$ ) represents the fallow lands, while the second (more than $4 \mathrm{~mm} / \mathrm{d}$ ) represents the sorghum fields. The $E T_{a}$ values for cotton during 6 September and 25 September ranged from 1.2 to $5.0 \mathrm{~mm} / \mathrm{d}$ and 2.8 to $5.0 \mathrm{~mm} / \mathrm{d}$, respectively (Table 2).

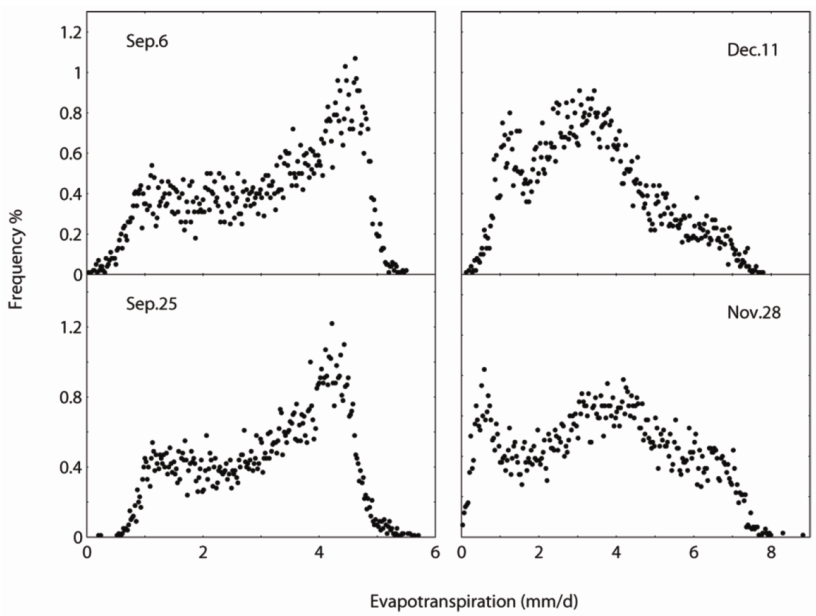

Figure 3. Actual evapotranspiration histogram during satellite days.

Table 1. Basic Statistics of Spatial Variation of Actual Evapotranspiration over the Study Area

\begin{tabular}{llll}
\hline \multirow{2}{*}{ Date } & \multicolumn{3}{l}{ Actual evapotranspiration } \\
\cline { 2 - 4 } & Mean & Mode & Standard deviation \\
\hline $6-09-2001$ & 3.2 & 4.6 & 1.3 \\
$11-12-2001$ & 3.9 & 3.4 & 2.1 \\
$25-09-2002$ & 3.2 & 4.2 & 1.2 \\
$28-11-2002$ & 3.6 & 3.6 & 1.9 \\
\hline
\end{tabular}

The spatial distribution patterns of $E T_{a}$ in late November and early December were very similar: the higher values were found in cotton fields, whereas the values for sorghum ranged 
from 1.7 to $4.4 \mathrm{~mm} / \mathrm{d}$ and from 1.4 to $3.4 \mathrm{~mm} / \mathrm{d}$, respectively (Table 2). The first peak during November and December which shows values of less than $1 \mathrm{~mm} / \mathrm{d}$ appeared mainly in the fallow land that had very low soil moisture in the root zone compared with irrigated land. Sorghum had low ET as it was due to harvesting, whereas cotton fields showed high ET values (more than $6 \mathrm{~mm} / \mathrm{d}$ ).

Table 2. Statistics of Daily Actual Evapotranspiration for Sorghum and Cotton

\begin{tabular}{lllllll}
\hline \multirow{2}{*}{ Date } & \multicolumn{2}{l}{ Sorghum } & \multicolumn{3}{l}{ Cotton } \\
\cline { 2 - 7 } & Mean & Max. & Min. & Mean & Max. & Min. \\
\hline $6-09-2001$ & 4.7 & 5.3 & 3.9 & 3.6 & 5.0 & 1.2 \\
$11-12-2001$ & 2.4 & 3.4 & 1.4 & 6.4 & 7.6 & 4.9 \\
$25-09-2002$ & 4.3 & 4.8 & 3.5 & 4.2 & 5.0 & 2.8 \\
$28-11-2002$ & 3.0 & 4.4 & 1.7 & 6.5 & 7.7 & 5.1 \\
\hline
\end{tabular}

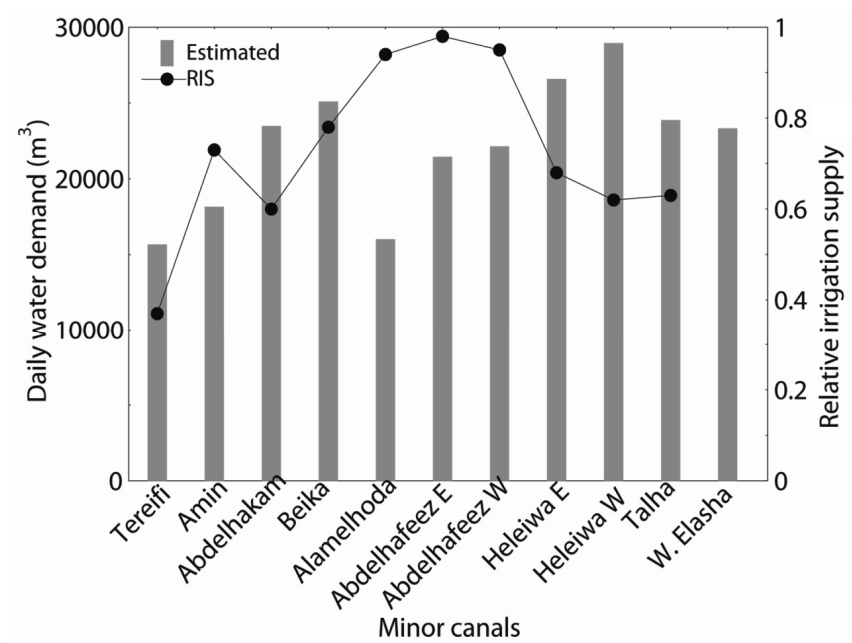

Figure 4. Daily water demand and relative irrigation supply (RIS) for different minor canals of Abdelhakam block during November.

The assessment of the spatial distribution of $E T_{a}$ by SEBAL allowed the estimation of water use for the irrigation system at different minor canals of the study area. Table 3 shows the water demand for different crops grown at each minor canal. For example, water consumption values for the Tereifi minor canal during 6 September, 25 September, 28 November and 11 December were 10,282, 11,383, 15,667 and $15,626 \mathrm{~m}^{3}$, respectively, representing critical information and key factors for irrigation water management. Daily water demand for all minor canals during November which represents a transition month with areas still having summer crops such as sorghum and cotton and new areas beginning to have winter crops such as wheat and some vegetables is shown in Figure 4. Daily demand ranges from $15,667 \mathrm{~m}^{3}$ for Tereifi to $28,954 \mathrm{~m}^{3}$ for Heleiwa west. Satellite remote sensing provides a tool to estimate crop acreage and net irrigation water requirements at canal level for each crop season. Thus the objective of efficient and sustainable water management can be achieved by optimal linkage between water available and water demand.
Knowing the water supply needed in all minor canals is requisite for computing water demand in all majors, and the needs of all majors are added up to compute the supply needed into the main canals. The demand thus estimated is supplied from the dam to satisfy the demand set for each minor and major canal. To extrapolate daily values to monthly and seasonal ET, the processing of several images taken during the growing season is requisite, as is a means of integrating daily ET into seasonal values.

Table 3. The Daily Demand of Water Derived by SEBAL for Different Minor Canals in the Study Area

\begin{tabular}{lll}
\hline Minor canal & Area in ha & Demand of water in $\mathrm{m}^{3}$ \\
\hline 6 September & & \\
Tereifi & 408 & 10282 \\
Amin & 496 & 13541 \\
Abdelhakam & 628 & 16140 \\
Beika & 684 & 18331 \\
\hline 25 September & & \\
Tereifi & 408 & 11383 \\
Amin & 496 & 13739 \\
Abdelhakam & 628 & 17835 \\
Beika & 684 & 22435 \\
\hline 28 November & & \\
Tereifi & 408 & 15667 \\
Amin & 496 & 18154 \\
Abdelhakam & 628 & 23487 \\
Beika & 684 & 25103 \\
\hline 11 December & & \\
Tereifi & 408 & 15626 \\
Amin & 496 & 19146 \\
Abdelhakam & 628 & 23613 \\
Beika & 684 & 27292 \\
\hline
\end{tabular}

Table 4. Evapotranspiration of Cotton as Estimated by Different Methods

\begin{tabular}{llll}
\hline Date & SEBAL & PM & $\mathrm{ET}_{\mathrm{c}}\left(E_{0} * k_{f}\right)$ \\
\hline $6-09-2001$ & 3.6 & 5.5 & 4.0 \\
$11-12-2001$ & 6.4 & 6.3 & 7.0 \\
$25-09-2002$ & 4.2 & 5.8 & 4.8 \\
$28-11-2002$ & 6.5 & 5.5 & 7.2 \\
\hline
\end{tabular}

The term relative irrigation supply indicates how well irrigation supply matches with the demand. Figure 4 highlights the values of relative irrigation supply, RIS (defined as the ratio of irrigation supply to irrigation demand) for different minor canals of Abdelhakam block. The RIS varies from 0.37 for Tereifi minor to 0.98 for Abdelhafeez minor canal, the average being 0.73 . The results showed plausible water supply for all minor canals $(0.6 \sim 0.98)$ except Tereifi minor which revealed a sever water scarcity (0.37). In general, relative irrigation supply equal or around one could be taken as an advantage in terms of crop water requirements. Values range from 0.60 to 0.78 could be considered as deficit irrigation practice that contribu- 
tes a lot for water conservation and irrigation efficiency improvement. In contrast, lower values of RIS are good indicator for sever water shortage.

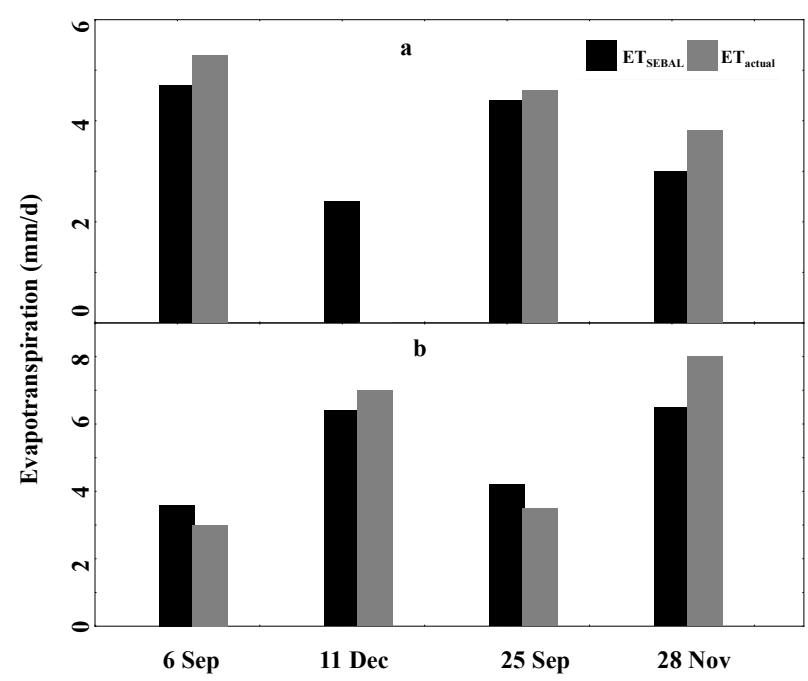

Figure 5. Comparison of SEBAL evapotranspiration with actual measurements values: (a) Sorghum and (b) Cotton.

Table 4 shows ET values of cotton estimated by SEBAL, PM reference ET and crop evapotranspiration $\left(E T_{c}=E_{0} \cdot k_{f}\right)$. The calculated $E T_{c}$ values were related to the original Penman evaporation from free water surfaces by crop factor $\left(k_{f}\right)$. The differences between estimated $E T_{c}$ and SEBAL ET values predicted on JDs 6 September, 11 December, 25 September and 28 November were $10 \%, 8.5 \%, 12.5 \%$ and $9.7 \%$, respectively. The average low difference indicated that the crop was not subjected to water stress during its growing cycle. The actual ET from SEBAL was lower than reference crop ET based on Penman-Monteith ( $\left.\mathrm{ET}_{0}-\mathrm{PM}\right)$ during September, corresponding to the expectaions during the September cotton crop and to the early stages of low evapotranspiration. During late November and early December, however, the actual ET values from SEBAL were higher than those from $\mathrm{ET}_{0}-\mathrm{PM}$, corresponding to the maximum growth stages of cotton when larger quantities of water were required.

Figure 5 demonstrates a comparison between SEBAL values and the actual field measurements obtained by the water balance method. The moisture content of the soil was regularly monitored by gravimetric sampling before and after each irrigation cycle, down to a depth of $100 \mathrm{~cm}$. All gravimetric samples were dried at $105^{\circ} \mathrm{C}$ for $24 \mathrm{~h}$, and routine weather data from the Gezira Meteorological Station (GMS) were taken into account.

The $E T_{a}$ values estimated for sorghum by SEBAL on the four satellite dates 6 September, 11 December, 25 September and 28 November were 4.7, 2.4, 4.4, and $3 \mathrm{~mm} / \mathrm{d}$, respectively. The actual ET values measured using WB on 6 September, 25 September and 28 November were $5.3,4.6$ and $3.8 \mathrm{~mm} / \mathrm{d}$, respectively; ET for 11 December was not measured because of the unavailability of gravimetric data. The absolute error be- tween the estimated values by SEBAL and the measured values by WB on the three JDs was $0.6,0.2$ and $0.8 \mathrm{~mm} / \mathrm{d}$, respectively. The good agreement between SEBAL and WB method in this study confirms other studies (Bashir et al., 2007) and indicates the potential of SEBAL in Gezira irrigated scheme under clear sky conditions. Other quantitative validations of evapotranspiration rates estimated from Landsat images using SEBAL have been reported by several authors (Allen et al., 2007a, b; Bastiaanssen et al., 2005).

Table 5. Crop Yield (1999-2001): Abdel Hakam Block Compared to Gezira Scheme*

\begin{tabular}{|c|c|c|c|}
\hline & $1999 / 2000$ & $2000 / 2001$ & Increase $\%$ \\
\hline \multicolumn{4}{|c|}{ Cotton (Yield kg $\cdot \mathrm{ha}^{-1}$ ) } \\
\hline Abdel Hakam & 1003 & 1878 & 87 \\
\hline Gezira scheme & 857 & 1596 & 86 \\
\hline Increase \% & 17 & 17 & \\
\hline \multicolumn{4}{|c|}{ Sorghum (Yield $\left.t \cdot h a^{-1}\right)$} \\
\hline Abdel Hakam & 1.19 & 2.93 & 146 \\
\hline Gezira scheme & 1.55 & 2.26 & 46 \\
\hline Increase \% & -29 & 30 & \\
\hline \multicolumn{4}{|c|}{ Wheat (Yield $\left.\mathrm{t} \cdot \mathrm{ha}^{-1}\right)$} \\
\hline Abdel Hakam & 0.48 & 2.26 & 375 \\
\hline Gezira scheme & 1.19 & 1.67 & 40 \\
\hline Increase \% & -60 & 36 & \\
\hline \multicolumn{4}{|c|}{ Groundnuts (Yield $\mathrm{t} \cdot \mathrm{ha}^{-1}$ ) } \\
\hline Abdel Hakam & 1.36 & 2.12 & 56 \\
\hline Gezira scheme & 2.05 & 2.05 & 3 \\
\hline Increase \% & -29 & 0 & \\
\hline
\end{tabular}

*Source: TCP/SUD/0065 National Project Coordinator Report (July 2000- October 2001).

For cotton, $E T_{a}$ values estimated by SEBAL on 6 September, 11 December, 25 September and 28 November were $3.6,6.4,4.2$ and $6.5 \mathrm{~mm} / \mathrm{d}$, respectively, whereas the corresponding actual values were $3,7,3.5$ and $8 \mathrm{~mm} / \mathrm{d}$, respectively. The absolute error between the estimated and measured values was $0.6,0.6,0.7$ and $1.5 \mathrm{~mm} / \mathrm{d}$, respectively. The average absolute error for both sorghum and cotton was estimated to be around $0.7 \mathrm{~mm} / \mathrm{d}$, denoting reliable agreement between the actual ET measurements and ET estimated by SEBAL for most of the images of both sorghum and cotton.

The close relation between the two values verified that the crops were well supplied by water and reflected the high yields of all the crops grown in the Abdel Hakam block compared with the average in the Gezira scheme (Table 5). In a study on the impact of the PP on crop productivity, Abdelhadi et al. (2004) compared the PP (Abdel Hakam block) with the four neighboring blocks, demonstrating that average increase in cotton yield ranged from $3 \%$ to $45 \%$ in the first season and $14 \%$ to $64 \%$ in the second season, whereas the average sorghum yield increased from $36 \%$ to $310 \%$ and $101 \%$ to $182 \%$ during the first and second seasons, respectively. The significant increase in outputs per unit of land considered as the most important impact of the participatory irrigation management carried by the PP. 
From the 2001 and 2002 seasons, SEBAL results clearly showed that farmers were able to deliver sufficient amounts of water to their fields, unlike previous seasons (before the PP). The primary reason for this positive change was probably due to the activities carried out by farmers before each season such as maintenance of canal banks, replacement of field outlet pipes, erection of new field outlet gates, and maintenance and erection of intermediate regulators. It is also clear that the transfer of the irrigation management authority to local irrigation committees chieved the objective of curtailing irrigation const and making irrigation management financially self-sustaining.

\section{Conclusions}

In this study, multidate ETM+ images and energy balance model were used to evaluate a PP in Abdel Hakam block supported by the FAO during 2000 2002. A comparison between SEBAL and actual measurements or conventional methods based on meteorological data showed plausible agreement, indicating that sorghum and cotton in these seasons (2001 and 2002) were not subjected to any kind of water stress. The daily values of water demand at different minor canals were successfully estimated. Relative irrigation supply indicated improvements in operational performance of irrigation during the period of the PP. Results revealed that the yields of major crops have increased significantly in Abdel Hakam block compared with the neighboring blocks as well as the scheme average. The PP supported by the FAO proved that the participatory water management approach can be successfully implemented to change the attitudes of farmers towards water management issues. The results of this temporal assessment are useful and encouragement to convince the donors to repeat the PP in several blocks of the Gezira scheme.

\section{References}

Abdelhadi, A.W., Bashir, M.A., Farah, S.M., and Hata, T. (2006). Implications of late sown irrigated grain sorghum on productivity and water management, Sudan J. Agric. Res., 6, 1-10.

Abdelhadi, A.W., Adam, H.S., Hassan, M.A., and Hata, T. (2004). Participatory management: Would it be a turning point in the history of the Gezira scheme, Irrig. Drain., 53, 429-436, doi:10.1002 /ird.139.

Abernethy, C.L. (1986). Performance measurement in canal water management: a discussion, ODI-IIMI Irrigation management Network Paper, No. 86/2d. London Overseas Development Institute.

Abdine, A.Z., and Farbrother, H.G. (1969). Prog. Rep. Exp. Station, Sudan, Cotton Research Corporation, London, pp. 67-68.

Allen, R.G., Pereira, L.S., Raes, D., and Smith, M. (1998). Crop evapotranspiration. Guidelines for coumputing crop water requirements, FAO Irrigation and Drainage, Paper No. 56.

Allen, R.G., Tasumi, M., and Trezza, R. (2007a). Satellite-based energy balance for mapping evapotranspiration with internalized calibration (METRIC)-model, J. Irrig. Drain. Eng., 133, 380-394, doi:10.1061/(ASCE)0733-9437(2007)133:4(380).

Allen, R.G., Tasumi, M., Morse, M., Trezza, R., Kramber,W., and Lorite, I. (2007b). Satellite-based energy balance for mapping evapotranspiration with internalized calibration (METRIC) - Applicacation, J. Irrig. Drain. Eng., 133, 395-406, doi:10.1061/(ASCE)0 733-9437(2007)133:4(395).
Bashir, M.A., Hata, T., Tanakamaru, H., Abdelhadi, A.W., and Tada, A. (2007). Remote sensing derived crop coefficient for estimating crop water requirements for irrigated sorghum in the Gezira scheme, Sudan, J. Env. Inform., 10(1), 47-54, doi:10.3808/jei. 200700 099.

Bastiaanssen, W.G.M., Menenti, M., Feddes, R.A., and Holtslag, A.A.M. (1998a). A remote sensing surface energy balance algorithm for land (SEBAL): 1. Formulation, J. Hydrol., 212-213, 198212, doi:10.1016/S0022-1694(98)00253-4.

Bastiaanssen, W.G.M., Pelgrum, H., Wang, J., Ma, Y., Moreno, J., Roerink, G.J., and van der Waal, T. (1998b). A remote sensing surface energy balance algorithm for land (SEBAL): 2. Validation, J. Hydrol., 212-213, 213-229, doi:10.1016/S0022-1694(98) 002534.

Bastiaanssen, W.G.M., Noordman, E.J.M., Pelgrum, H., Davids, G., Thoreson, B.P., and Allen, R.G. (2005). SEBAL model with remotely sensed dat to improve water-resources management under actual field conditions, J. Irrig. Drain. Eng., ASCE, 131, 85-93.

De Bruin, H.A.R. (1987). From penman to Makkink, in J.C. Hooghart (Ed.), Proceedings and Information, TNO Committee on Hydrological Research, 39, Gravenhage, The Netherlands.

FAO TCP/SUD/0065 (2001). Raising productivity through broadening farmer's choice on farming systems and water management, National Project Coordinator Report, Khartoum, Sudan, pp. 1-8.

Kustas, W.P., Pinker, R.T., Schmugge, T.J., and Humes, K.S. (1994). Daytime net radiation estimated for a semi arid range land basin from remotely sensed data, Agric. For. Meteorol., 59, 341-362.

Levine, G. (1982). Relative water supply: an explanatory variable for irrigation systems, Technical Report No. 6. Cornell University, Ithaca, New York, USA.

Molden, D., and Gates, T.K. (1990). Performance measures for evaluation of irrigation water delivery systems, J. Irrig. Water Eng., ASCE, 116(6), 804-823, doi:10.1061/(ASCE)0733-9437 (1990)116: $6(804)$.

Moran, M.S. and Jackson, R.D. (1991). Assessing the spatial distribution of evapotranspiration using remotely sensed inputs, J. Environ. Qual., 20, 725-737.

Morse, A., Tasumi, M., Allen, R.G., and Kramber, W. (2000). Application of the SEBAL Methodology for Estimating Consumptive Use of Water and Stream Flow Depletion in the Bear River Basin of Idaho through Remote Sensing, Final report, EOSDIS, Idaho Department of Water Resources and University of Idaho, pp. 107.

Nichols, W.E., and Cuenca, R.H. (1993). Evaluation of the evaporation fraction for parameterization of the surface energy balance, Water Resour. Res., 29, 3681-3690.

Paulson, C.A. (1970). The mathematical representation of windspeed and temperature profiles in unstable atmospheric surface layer, $J$. Appl. Meteorol., 9, 857-861, doi:10.1175/1520-0450(1970)009<0 857:TMROWS $>2.0 . \mathrm{CO} ; 2$.

Shuttleworth, W.J., Gurney, R.J., Hsu, A.Y., and Ormbsy, J.P. (1989). FIFE: the variation in energy partitioning at surface flux sites, remote sensing and large scale global processes, in Proc. of the Baltimore Symposium IAHS ,Publication No. 186, IAHS press, Oxfordshire, pp. 67-74.

Tasumi, M. (2003). Progress in Operational Estimation of Regional Evapotranspiration Using Satellite Imagery, Ph.D. Dissertation, University of Idaho, USA, pp. 357.

Van de Griend, A.A., and Owe, M. (1993). On the relationship between thermal emissivity and the normalized difference vegetation index for natural surfaces, Int. J. Remote Sens., 14(6), 11191131.

Van Oevelen, P.J., Kustas, W.P., and Daughton, C.S.T. (1993). Estimates of the available energy for evapotranspiration with the use of remote sensing: A simple modeling approach, EARSel Adv. Remote Sens., 2(2-VI), 100-109. 